\title{
Hypothalamic-Pituitary-Adrenal Activity in Aged, Cognitively Impaired and Cognitively Unimpaired Rats
}

\author{
Amalia M. Issa, ${ }^{1,3}$ Wayne Rowe, ${ }^{1}$ Serge Gauthier, ${ }^{2,3}$ and Michael J. Meaney, \\ 'Developmental Neuroendocrinology Laboratory, Douglas Hospital Research Centre, Department of Psychiatry, ${ }^{2}$ McGill \\ Centre for Studies in Aging, and 'Department of Neurology and Neurosurgery, McGill University, Montreal, Canada
}

There is a tendency for increased hypothalamic-pituitaryadrenal (HPA) activity with age in the rat, and the resulting elevations in circulating glucocorticoid levels have been implicated in the occurrence of hippocampal pathology and memory deficits. In the experiments reported here, we examined whether HPA dysfunction is selectively associated with cognitive impairments in a population of aged rats. Fiftyeight 23-27-month-old male Long-Evans rats were screened for spatial memory impairments using the Morris swim maze, and 2 groups of aged animals were selected: aged, cognitively impaired (AI) animals whose performance was significantly different (>2 SD) from that of 6-month-old controls and aged, cognitively unimpaired (AU) animals whose performance was comparable to that of the young controls (a difference of $<0.5$ SD). Twenty-eight percent of the animals tested were designated as $\mathbf{A l}$ and $20 \%$ as AU. Histological analysis of a subset of these animals showed that, while both $\mathrm{AU}$ and $\mathrm{Al}$ animals showed neuron loss in the pyramidal cell fields of the hippocampus, the loss was significantly greater in the Al animals. The Al animals showed clear evidence of increased HPA activity. Thus, basal ACTH and corticosterone levels were significantly higher in the Al animals compared with both $\mathrm{AU}$ animals and young controls, especially during the dark phase of the cycle. The Al, AU, and young animals exhibited comparable corticosterone levels during a 20-min immobilization stress; however, following the termination of the stressor, corticosterone levels in Al animals were significantly elevated compared with both AU animals and controls. The AU animals did not differ from the young controls on any measure of HPA function. These findings suggested impaired glucocorticoid negative feedback in the Al animals. Both $A U$ and $A I$ animals showed reduced hippocampal type I and type II corticosteroid-receptor binding; however, the reduction was significantly greater in the Al animals. There were no differences in receptor binding in the hypothalamus or pituitary, and these findings are consistent with the idea that age-related HPA dysfunction is associated with the loss of hippocampal corticosteroid re-

\footnotetext{
Received Jan. 31, 1990; revised June 7, 1990; accepted June 18, 1990.

This work was supported by research grants from the Medical Research Council of Canada and le Fonds de Recherche en Sante du Quebec to M.J.M., who is a University Research Fellow of the Natural Sciences and Engineering Research Council. We also acknowledge the generous support of the ALCAN Aluminium Ltd. of Canada for the Aging Research Program at the Douglas Hospital Research Centre.

Correspondence should be addressed to Michael J. Meaney, Douglas Hospital Research Centre, 6875 Boulevard LaSalle, Montreal, Quebec H4H IR3, Canada. Copyright (C) 1990 Society for Neuroscience $0270-6474 / 90 / 103247-08 \$ 03.00 / 0$
}

ceptors. These data suggest that HPA dysfunction among aged animals is selectively associated with spatial memory impairments and increased hippocampal neuron loss and does not emerge merely as a function of age.

Basal levels of hypothalamic-pituitary-adrenal (HPA) activity tend to increase with age in the rat, resulting in elevated plasma levels of ACTH and corticosterone (Sencar-Cupovic and Milkovic, 1976; Tang and Philips, 1978; Brett et al., 1983, 1986; Sapolsky et al., 1983a; DeKosky et al., 1984; Meaney et al., 1988a, 1990a; but see also Sonntag et al., 1987). This increase in HPA activity appears to occur as a function of dampened glucocorticoid negative-feedback inhibition over HPA activity. Thus, aged rats showed reduced HPA suppression following exogenous treatment with either corticosterone (Sapolsky et al., 1986a) or dexamethasone (Dilman, 1981). The decreased glucocorticoid inhibition of HPA activity is, in turn, likely associated with a loss of corticosteroid receptors in certain brain regions that mediate the negative-feedback effects of circulating glucocorticoids. Specifically, there is a decrease of both type I (mineralocorticoid-like) and type II (glucocorticoid) corticosteroid receptors in the hippocampus of the aged rat (Sapolsky et al., 1983b; Ritger et al., 1984; Meaney et al., 1988a, 1990a,b; Reul et al., 1988).

The increased exposure to the highly catabolic adrenal glucocorticoids appears to be associated with the loss of hippocampal neurons and the emergence of cognitive deficits in the aged rat. The hippocampus contains the greatest density of corticosteroid receptors in the brain (McEwen et al., 1986), and it seems that this high sensitivity to adrenal steroids in the presence of the elevated corticosterone titers often seen in aged rats promotes hippocampal neuron loss, especially the loss of pyramidal cells. [Note that this effect may depend on the age of the animal, as peripubertal rats show granule cell loss in the absence of glucocorticoids; see Slovitar et al. (1989).] Among a population of aged rats, the magnitude of hippocampal neuron loss and memory deficits is positively correlated with the increase in adrenal activity (Landfield et al., 1978). Moreover, animals adrenalectomized at midlife (with low-level corticosterone replacement) show reduced neuron loss in the hippocampus and improved cognitive functioning compared with intact, control animals (Landfield et al., 1981). Sapolsky et al. (1985) found that young adult animals, exposed daily to an exogenous corticosterone administration that produced glucocorticoid levels in the upper physiological range, showed profound hippocampal neuron loss following 3 months of treatment. Interestingly, the loss was greatest in corticosterone-sensitive neurons, and the pattern of neuron loss was similar to that occurring in the aged 
rat. Therefore, a treatment that mimics the elevated corticosterone levels commonly observed in aged rats is sufficient to produce hippocampal neuron loss, even in young, healthy animals.

It is entirely likely that such hippocampal damage underlies, at least in part, age-related deficits in spatial memory in the rat, because among young animals, hippocampal lesions are consistently associated with these forms of cognitive impairments (e.g., Morris, 1985). However, it is now apparent that not all aged rats manifest spatial memory impairments (e.g., Gage et al., 1984; Gage and Bjorklund, 1986; Pelleymounter et al., 1990). For example, Gage et al. (1984), using the Morris swim maze as a test of spatial memory (Morris, 1985), found that about $30-40 \%$ of aged rats showed clearly impaired cognitive performance. About $35 \%$ of the aged animals performed as well as young adult animals. These findings reflect the considerable variation in spatial memory ability among aged rats. Such individual differences arc also charactcristic of human populations and are likely a central feature of CNS aging in mammalian species (see Rowe and Kahn, 1987).

If HPA dysfunction is associated with hippocampal pathology and not merely with advanced age, then we would expect that a sample of aged, cognitively impaired animals and aged, cognitively unimpaired animals should differ considerably in HPA activity. In the experiments reported here, we have examined this idea using a screening procedure comparable to that of Gage et al. (1984), selecting animals on the basis of their performance in the Morris swim maze as compared with that of 6-monthold controls. The results indicate that increased HPA activity is indeed selectively associated with progressed hippocampal neuron loss and spatial memory deficits such that aged, cognitively unimpaired animals do not differ from young controls in measures of basal or stress-induced HPA activity.

\section{Materials and Methods}

Animals. The aged animals used in these studies were male Long-Evans hooded rats (Charles River Canada, St. Constant, Quebec) obtained at 6-7 months of age. The young controls were obtained from the same supplier at 3-4 months of age. The animals were housed 3 per cage (45 $\times 30 \times 18 \mathrm{~cm}$ ) and maintained on a 12:12 light-dark schedule (lights on at 0800 ) at $22^{\circ} \mathrm{C}, 45-55 \%$ humidity, with free access to food (Purina Lab Chow) and water. At the time of the experiments, the animals were 6-7 months of age (young controls) or 23-27 months of age (aged). The health of the animals was monitored regularly, and any animals with overt signs of chronic respitatory distress, infection, or tumors were removed from the study. In addition, we maintain a "sentinel" program overseen by the veterinary staff at McGill University. Under this program, specific animals caged in the same location and under the same conditions as our aged animals are blood tested every 3 months and killed at 6 months in order to monitor the health of the animals in our facility and to screen for the presence of viruses or other forms of infection. To date, we have observed a mortality rate of $<2 \%$ by 24 months and $\sim 10 \%$ by 28 months of age.

Behavioral screening. Fifty-eight aged animals were screened using a version of the Morris swim maze test, and their performance was compared to that of 19 young controls. The animals were required to find a platform submerged $(2 \mathrm{~cm})$ in a $1.6-\mathrm{m}$-diameter pool of opaque water using only distal, spatial cues available within the testing room. The platform was hidden in 1 of 4 quadrants halfway between the sidewalls and the center of the pool. Each trial began with the animal placed into the pool facing the sidewalls at either the north, south, east, or west positions in a quasi-random sequence requiring the animals to swim in different directions on successive trials. Each trial ended when the animal found the platform and remained there for $10 \mathrm{sec}$. If the animal did not find the platform, the trial was terminated after $120 \mathrm{sec}$. Rats are proficient but reluctant swimmers and readily use the platform to escape the water. The animals were given 12 trials over $3 \mathrm{~d}$ with the platform submerged. At the end of the testing period with the platform in the submerged position, the animals actually sclected for the experiments were given 5 trials to locate a platform that was raised $2 \mathrm{~cm}$ above the water level (visually cued condition; see Morris, 1985). This condition was used to ensure that impairments were not related to the animals inability to perform the motor demands of the task (see Gage et al., 1984).

Hippocampal cell counting. Cell counting was performed on $20-\mu \mathrm{m}$ Cresyl violet-stained sections of the dorsal hippocampus as previously described (Meaney et al., 1988a). Briefly, raw cell counts were obtained using a $250 \times 250-\mu \mathrm{m}$ grid over a $40 \times$ magnified section with a light microscope. Three to 5 sections of dorsal hippocampus [corresponding to Plates 21 or 22 of the rat brain atlas of Paxinos and Watson (1982)] were analyzed for each animal. Raw cell counts of the pyramidal cell fields were transformed into measures of neuron density per $0.1 \mathrm{~mm}^{2}$ using the method of Abercrombie (1946) to correct for split-cell artifacts. The medial-lateral length of the cell fields was estimated using camera lucida tracings onto a graphics tablet that provided a measure of the length of each cell field. We also estimated the rostral-to-caudal extent of the dorsal hippocampus in each animal by counting the number of $20 \mu \mathrm{m}$ sections between Plate 19 and Plate 23 of the atlas of Paxinos and Watson. These estimates were made to ensure that differences in neuron density were not due to changes in either the medial-lateral or rostral-caudal dimensions of the cell fields.

Blood sampling under basal and stressful conditions. Basal corticosterone levels over the diurnal cycle were measured as previously described (e.g., Meaney et al., 1989a). Briefly, blood samples $(\sim 50 \mu$ l) were taken from the tail vein at 6 points over a 24-hr cycle. In these studies, animals were housed in groups of 3 animals per cage, and only 1 animal per cage was actually sampled. Blood samples were taken in heparinized tubes, placed on ice, centrifuged, and stored at $-30^{\circ} \mathrm{C}$ until assayed. Blood samples $(250 \mu \mathrm{l})$ for ACTH determination were taken at a separate time, $2 \mathrm{hr}$ following the time of lights on (1000, light phase) and off (2200, dark phase) in tubes containing EDTA and Trasylol, centrifuged, stored at $-80^{\circ} \mathrm{C}$, and assayed for plasma ACTH within 1 week of the experiment. (Note that, because of the larger sample required, sampling for ACTH levels occurs only at 2 time points.) In all cases, animals were sampled less than 10 sec following their removal from their home cages in order to obtain valid estimates of basal hormone levels.

Restraint stress was performed between 1100 and 1300 using tubular, plastic restrainers lined with foam rubber. The animals were placed into the restrainers for a $20-\mathrm{min}$ period. A blood sample $(\sim 50 \mu \mathrm{l})$ was taken immediately before the animal was placed into the restrainer, and this sample was used as an estimate of basal corticosterone levels prior to stress. Blood samples $(\sim 50 \mu)$ were then taken from the same animals at various times during and following the termination of the stressor. The time 0 point was taken just before releasing the animals from the restrainers (i.e., $0 \mathrm{~min}$ following termination of the stressor) and represents the peak stress value.

Radioimmunoassays. Plasma corticosterone was measured using the radioimmunoassay of Krey et al. (1975) with a highly specific corticosterone antiserum (B3-163, Endocrine Sciences, Tarzana, CA) and ${ }^{3} \mathrm{H}-$ corticosterone $(101.0 \mu \mathrm{Ci} / \mathrm{mmol}$; New England Nuclear, Boston, MA) as tracer. The minimum level of detection with the assay is $10 \mathrm{pg} / \mathrm{ml}$. The antiserum cross-reacts slightly with desoxycorticosterone $(\sim 4 \%)$, but not with cortisol $(<1 \%)$. The intra- and interassay coefficients of variation are 8.9 and $11.2 \%$, respectively. Plasma ACTH was measured using the radioimmunoassay kit of ICN-Biomedicals (Carson, CA) with ${ }^{125}$ I-ACTH as tracer. The ACTH antibody cross-reacts $100 \%$ with $\mathrm{ACTH}_{1-39}$ and $\mathrm{ACTH}_{1-24}$, but less than $1 \%$ with $\beta$-endorphin, $\alpha$ - and $\beta$-MSH, and $\alpha$ - and $\beta$-lipotropin. The intra- and interassay coefficients of variation are 6.0 and $10.7 \%$, respectively. The minimal detectable level of plasma ACTH is about $5 \mathrm{pg} / \mathrm{ml}$.

Corticosteroid-receptor binding assays. Animals were killed by decapitation 12-14 hr following adrenalectomy, a time period that allows for the clearance of the endogenous steroid. Following decapitation, the brain was quickly removed and placed on ice, and the hippocampus, hypothalamus, and pituitary were dissected, frozen on dry ice, and stored at $-80^{\circ} \mathrm{C}$ until assayed. The tissue was homogenized in $30 \mathrm{~mm}$ Tris, $1 \mathrm{~mm}$ EDTA, $10 \mathrm{~mm}$ sodium molybdate, $10 \% \mathrm{v} / \mathrm{v}$ glycerol, and $1 \mathrm{~mm}$ dithiothreitol (TEDGM) ( $\mathrm{pH}$ adjusted to 7.4). The homogenate was centrifuged at $2^{\circ} \mathrm{C}$ for 60 min at 105,000 $\times g$ in a Beckman L8-80 ultracentrifuge. For determination of type II glucocorticoid-receptor binding capacity, aliquots $(150 \mu \mathrm{l})$ of the soluble fraction were incubated with 100- $\mu$ l aliquots of TEDGM containing a saturating, 15-nM concentration of ${ }^{3} \mathrm{H}-\mathrm{RU} 28362(77.9 \mathrm{Ci} / \mathrm{mmol}$; New England Nuclear, Bos- 
ton, MA) at $0-4^{\circ} \mathrm{C}$ for $20-22 \mathrm{hr}$ (a time that has been shown to be sufficient for maximal exchange to occur and during which binding is stable; see Kalimi and Hubbard, 1983; Reul and De Kloet, 1985; Mitchell et al., 1986; Reul et al., 1987; Meaney et al., 1988b). We routinely use exchange conditions in binding experiments in order to minimize the effects of any residual steroid in the tissue. Nonspecific binding was determined in parallel incubations containing a 200 -fold excess of unlabeled corticosterone. RU 28362 has been shown to selectively bind to the glucocorticoid receptor, showing very little affinity for the mineralocorticoid receptor (Philibert and Moguilewsky, 1983; Coirini et al., 1985).

Type I mineralocorticoid-like receptor binding capacity in the hippocampus was measured using ${ }^{3} \mathrm{H}$-corticosterone in a manner previously described by Reul and De Kloet (1985). Aliquots $(150 \mu 1)$ of soluble fractions prepared from hippocampal tissue were incubated at $0-4^{\circ} \mathrm{C}$ for $20-22 \mathrm{hr}$ in the presence of a saturating $20-\mathrm{nM}$ concentration of ${ }^{3} \mathrm{H}$ corticosterone $(105.0 \mu \mathrm{Ci} / \mathrm{mmol}$; New England Nuclear, Boston, MA) in TEDGM with a 50-fold excess of cold RU 28362 in order to preclude binding of the radioligand to type II sites. Nonspecific binding was determined in parallel incubations containing a 200 -fold excess of unlabeled corticosterone.

Sephadex LH-20 columns $(4 \times 1 \mathrm{~cm})$, made from disposable pipette tips and equilibrated with TEDGM, were used to separate bound from unbound steroids. Following the incubation, $100 \mu l$ of the incubates was washed into the columns with $100 \mu \mathrm{l}$ TEDGM. The columns were eluted 30 min later with $500 \mu \mathrm{l}$ TEDGM, into minivials, which were then filled with $5 \mathrm{ml}$ of Liquiscent (National Diagnostics, Somerville, NJ) and counted in a Packard scintillation counter at $40 \%$ efficiency. Protein content was determined using the method of Bradford (1976), and the results were expressed as $\mathrm{fmol} / \mathrm{mg}$ protein-specific binding. Protein concentrations ranged from 300 to $500 \mu \mathrm{g} / \mathrm{ml}$ for the hippocampal assays and from 200 to $300 \mu \mathrm{g} / \mathrm{ml}$ for the hypothalamus and pituitary assays.

Plasma corticosteroid-binding globulin (CBG) levels were measured using the method described by Martin et al. (1977) in plasma samples taken either $2 \mathrm{hr}$ into the light cycle (1000) or $2 \mathrm{hr}$ into the dark cycle (2200). Endogenous steroids were removed from plasma samples by passing the sample through a $10 \times 1-\mathrm{cm}$ Sephadex LH-20 column. In the process, the plasma was diluted 50:1 with TEDGM (pH, 7.4). Aliquots $(225 \mu)$ of the diluted plasma were then incubated in buffer $(150$ ul) containing a saturating $80-\mathrm{nM}$ concentration of ${ }^{3} \mathrm{H}$-corticosterone for $90 \mathrm{~min}$ at $2-4^{\circ} \mathrm{C}$ (see Martin et al., 1977). Nonspecific binding was defined in parallel incubations using a 200-fold excess of cold corticosterone. Separation of bound from free protein estimations, the processing of eluates, and the analysis of the data was performed as described above.

Statistical analysis. Unless otherwise stated, the data were analyzed using an analysis of variance with Scheffe post hoc test performed when appropriate.

\section{Results}

Behavioral screening of aged animals. The aged animals used in these experiments were selected from a population of 58 rats 23-27 months of age. Overall, the performance of the animals within this group did not vary as a function of age. For the purpose of selecting the animals, the performance of each animal was averaged over blocks of 4 trials, corresponding to each day of testing. The AI group was comprised of animals whose performance on the second and third $d$ of testing (data collapsed over a block of 4 trials) differed significantly ( $>2$ SD) from the mean performance of the young controls $(n=19)$. Animals were considered $\mathrm{AU}$ if their performance did not differ from the mean of young controls by more than $0.5 \mathrm{SD}$ on either the second or third day of testing. The data from the first day was not considered as a basis of selection because most animals, regardless of status, tend to perform poorly in the initial phase of the testing. Of the 58 animals tested, $16(28 \%)$ were designated AI, $20(34 \%) \mathrm{AU}$, and 22 fell in between and were excluded from the study. For any subsequent experiment, animals were randomly chosen from these groups.

Statistical analysis of the latency data for the animals used in

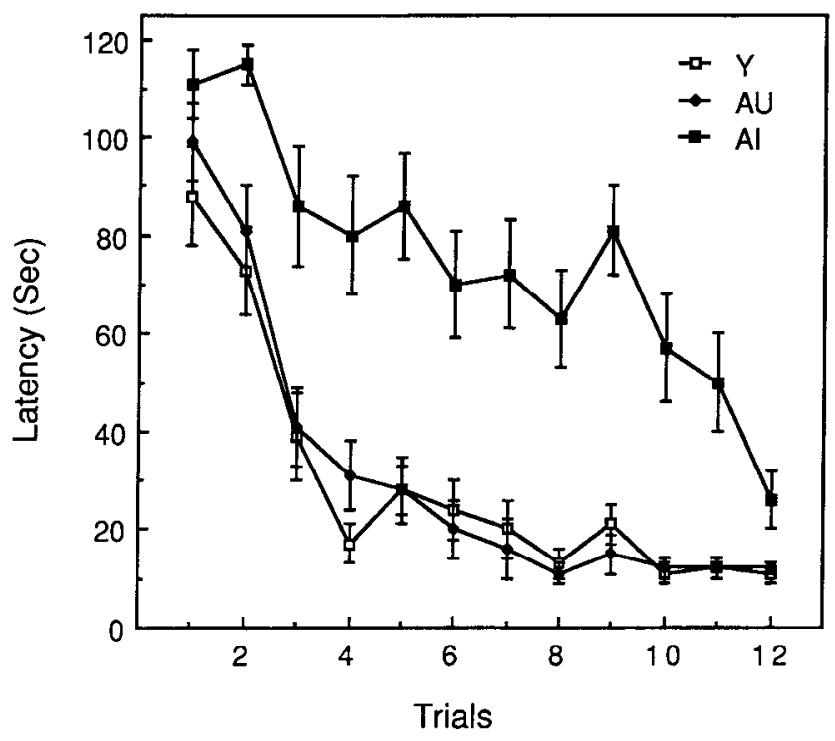

Figure 1. Mean ( \pm SEM) latency to locate submerged platform in Morris swim maze in $A I, A U$, and young control $(Y)$ animals over trials (AI differ from AU and $\mathrm{Y}$ on trials 3-12, $p<0.05$ ).

these experiments revealed that the performance of the AI animals differed significantly $(p<0.01)$ from that of the $\mathrm{AU}$ animals and the young controls on trials 3-12 (see Fig. 1). The $\mathrm{AU}$ animals and young controls did not differ reliably at any point in testing. The animals were then given 5 trials in which the platform was elevated $1.5 \mathrm{~cm}$ above the water level. Under these conditions, there were no significant group differences at any time (all group means $<10 \mathrm{sec}$ ). These data suggest that the differences in the ability of the animals to locate the submerged platform was not due to any motor-performance deficits.

Hippocampal neuron density. Four animals from each group were randomly selected for analysis of hippocampal neuron loss (with the subsequent loss of the tissue from $1 \mathrm{AU}$ animal during processing). There were no significant group differences in the length of any of the 4 pyramidal cell fields nor in the rostralcaudal extent of the dorsal hippocampus (see Table 1). The neuron density data were analyzed separately for each of the 4 cell fields of Ammon's horn (sce Fig. 2). There was significant hippocampal neuron loss in both AI and AU animals, though the loss was consistently greater in the AI group. The most prominent decrease in neuron density occurred in the $\mathrm{CA}_{1}$ and

Table 1. Mean ( \pm SEM) length of hippocampal cell fields and the rostral-caudal extent of dorsal hippocampus in $A I, A U$, and young control animals

\begin{tabular}{lccl} 
Measure $^{a}$ & $\mathrm{AI}$ & $\mathrm{AU}$ & $\mathrm{Y}$ \\
\hline $\mathrm{CA}_{1}$ length & $9.7 \pm 0.2$ & $9.1 \pm 0.7$ & $9.6 \pm 0.2$ \\
$\mathrm{CA}_{2}$ length & $2.0 \pm 0.2$ & $1.7 \pm 0.1$ & $2.3 \pm 0.4$ \\
$\mathrm{CA}_{3}$ length & $5.0 \pm 0.2$ & $5.5 \pm 0.4$ & $5.6 \pm 0.2$ \\
$\mathrm{CA}_{4}$ length & $5.6 \pm 0.1$ & $5.6 \pm 0.2$ & $5.6 \pm 0.3$ \\
Rostral-caudal extent & $220 \pm 18$ & $223 \pm 11$ & $228 \pm 10$
\end{tabular}

$\mathrm{Y}$, young control animals; $n=3-4$ animals per group for all measurements. ${ }^{a}$ Values for CA lengths are expressed as $\mathrm{mm} \pm \mathrm{SEM}$; values for the rostral-caudal extent are expressed as the number of $20-\mu \mathrm{m}$ sections. 


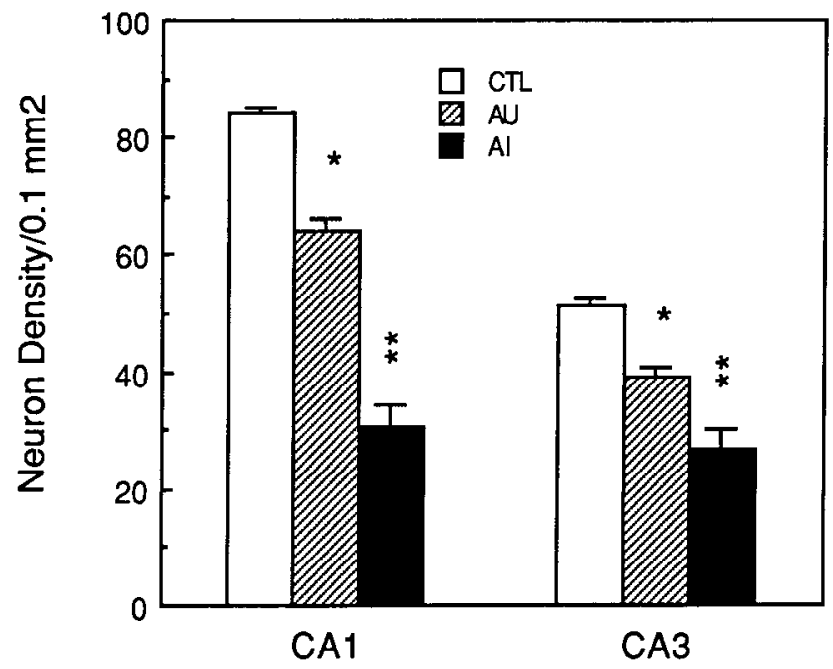

Figure 2. Mean ( \pm SEM) neuron density (per $\left.0.1 \mathrm{~mm}^{2}\right)$ in hippocampal pyramidal cell fields in $A I, A U$, and young control $(C T L)$ animals $(n=$ 3-4 animals per group; ${ }^{*}, p<0.01$ ).

$\mathrm{CA}_{3}$ cell fields (see Fig. 3). In these regions, both $\mathrm{AI}$ and $\mathrm{AU}$ animals differed from controls $(p<0.01)$, and the AI animals showed significantly $(p<0.01)$ greater decreases in neuron density than did the AU animals. In the $\mathrm{CA}_{2}$ cell field, only the $\mathrm{AI}$ animals showed significantly $(p<0.05)$ decreased neuron density compared with the young controls (controls, $49.6 \pm 3.1$; $\mathrm{AU}, 48.7 \pm 3.0 ; \mathrm{AI}, 35.4 \pm 3.8$ ). Likewise, in the $\mathrm{CA}_{4}$ field, the AI animals showed reduced neuron density, but differed significantly $(p<0.01)$ from only the young controls (controls, $40.5 \pm 1.8 ; \mathrm{AU}, 27.1 \pm 1.7 ; \mathrm{AI}, 21.7 \pm 4.3$ ).

Basal and stress-induced HPA function. Basal corticosterone levels (see Fig. 4) showed a significant circadian variation $(p<$ 0.001 ), with the peak in corticosterone levels in all groups occurring at the onset of the dark period (i.e., 2000). There were no significant differences in corticosterone levels at any time between $\mathrm{AU}$ and control animals. In contrast, basal corticosterone levels in AI animals were significantly $(p<0.01)$ higher than those in either AU or control animals at 1600,2400, and 0400. Twenty-four-hour 'secretion' rates, as determined using an area-under-the-curve analysis of the basal samples, revealed that corticosterone levels in $\mathrm{AI}$ animals were about $60 \%$ higher $(p<0.001)$ than in AU and control animals over the entire diurnal period (controls, $9.5 \pm 0.6 \mu \mathrm{g} / \mathrm{dl} / \mathrm{hr}$; AU, $9.3 \pm 0.3 \mu \mathrm{g}$ / $\mathrm{dl} / \mathrm{hr} ; \mathrm{AI}, 15.1 \pm 0.6 \mu \mathrm{g} / \mathrm{dl} / \mathrm{hr}$ ). Basal plasma ACTH levels showed basically the same pattern (see Fig. 5). There were no significant group differences in the light phase of the cycle; however, during the dark phase, $\mathrm{AI}$ animals showed significantly ( $p$ $<0.01$ ) higher plasma ACTH levels than did either AU or control animals.

Analysis of the stress-induced changes in HPA activity showed that (1) basal prestress corticosterone levels were significantly $(p<0.05)$ higher in the AI animals, (2) there were no group differences in the peak levels of corticosterone achieved during stress (time 0 data), and (3) AI animals had significantly ( $p<$ 0.01 ) higher plasma corticosterone levels at each time point following the termination of the stressor (i.e., at $30 \mathrm{~min}$ poststress and thereafter; see Fig. 6). Thus, AI animals were impaired in their capacity to reduce corticosterone levels following the termination of the stressor. This difference can also be illustrated
Table 2. Mean ( \pm SEM) plasma corticosterone-binding globulin levels in $\mathrm{AI}, \mathrm{AU}$, and young control animals during the light and dark phases of the cycle

\begin{tabular}{llll} 
& AI & AU & Y \\
\hline AM & $7.8 \pm 1.1$ & $5.9 \pm 0.8$ & $7.9 \pm 0.6$ \\
PM & $7.4 \pm 1.1$ & $7.6 \pm 1.0$ & $6.0 \pm 0.6$
\end{tabular}

Values are expressed as mean pmol/mg protein \pm SEM; $n=3-4$ animals per group. Y, young control animals; AM, light phase of cycle; PM, dark phase of cycle.

by estimating the cumulative percentage of animals in each group that showed "recovery" to basal steady-state corticosterone levels following the termination of restraint stress. Recovery is defined as the basal (prestress) value for that animals $\pm 20 \%$. As long as $180 \mathrm{~min}$ following the end of restraint stress, only $40 \%$ of the AI animals exhibited plasma corticosterone levels that approximated their prestress values, compared with $>90 \%$ of both $\mathrm{AU}$ and control animals.

Corticosteroid-receptor binding. The analysis of the results of the hippocampal costicosteroid-receptor binding assays (see Fig. 7) showed a significant $(p<0.05)$ decrease in type II receptors in both groups of aged animals. The decrease was significantly $(p<0.05)$ greater in the AI animals. The AI animals also showed significantly $(p<0.05)$ reduced hippocampal type I receptor binding capacity. Thus, the overall loss of hippocampal corticosteroid receptors was considerably greater in the AI animals. The groups did not differ in type II receptor binding in the hypothalamus (controls, $132.4 \pm 13$; AU, $154.4 \pm 26$; AI, 119.0 $\pm 11 \mathrm{fmol} / \mathrm{mg}$ protein) or in the pituitary (controls, $209.4 \pm$ 55; AU, $165.1 \pm 10 ; \mathrm{AI}, 236.7 \pm 31 \mathrm{fmol} / \mathrm{mg}$ protein). Finally, there were no differences in plasma CBG levels during either the light or dark phases of the cycle (see Table 2). It is important to note that CBG is the principle plasma binder for corticosterone, and Partridge et al. (1983) have shown that the brain uptake of corticosterone approximates the non-CBG-bound portion of the steroid. Thus, the absence of any difference in plasma CBG levels suggests that the percentage of free corticosterone (the biologically active form of the steroid) is comparable across groups, and that the total corticosterone values presented above reflect the actual differences in the magnitude of the corticoid signal in circulation.

\section{Discussion}

These data suggest that neither spatial memory impairments nor increased HPA activity are an inevitable consequence of aging in the rat. The behavioral screening revealed evidence of cognitive impairments in only about $30 \%$ of the animals tested. In subsequent studies, we have tested about 50 more animals, and the percentage of those classified as aged, impaired remains between 30 and $35 \%$. This estimate is similar to that obtained in the previous studies of Gage (1984) and Gage and Bjorklund (1986). In our animals, spatial memory impairments were associated with a more pronounced loss of hippocampal neurons throughout the pyramidal cell fields: AI animals showed marked decreases in neuron density in all areas examined, whereas the AU animals showed a more modest loss that was detected only in $\mathrm{CA}_{1}$ and $\mathrm{CA}_{3}$. Gage et al. (1984) found that spatial memory impairments in aged rats were selectively associated with decreased hippocampal glucose metabolism. Likewise, Pelleymounter et al. (1988) reported that aged, impaired animals 


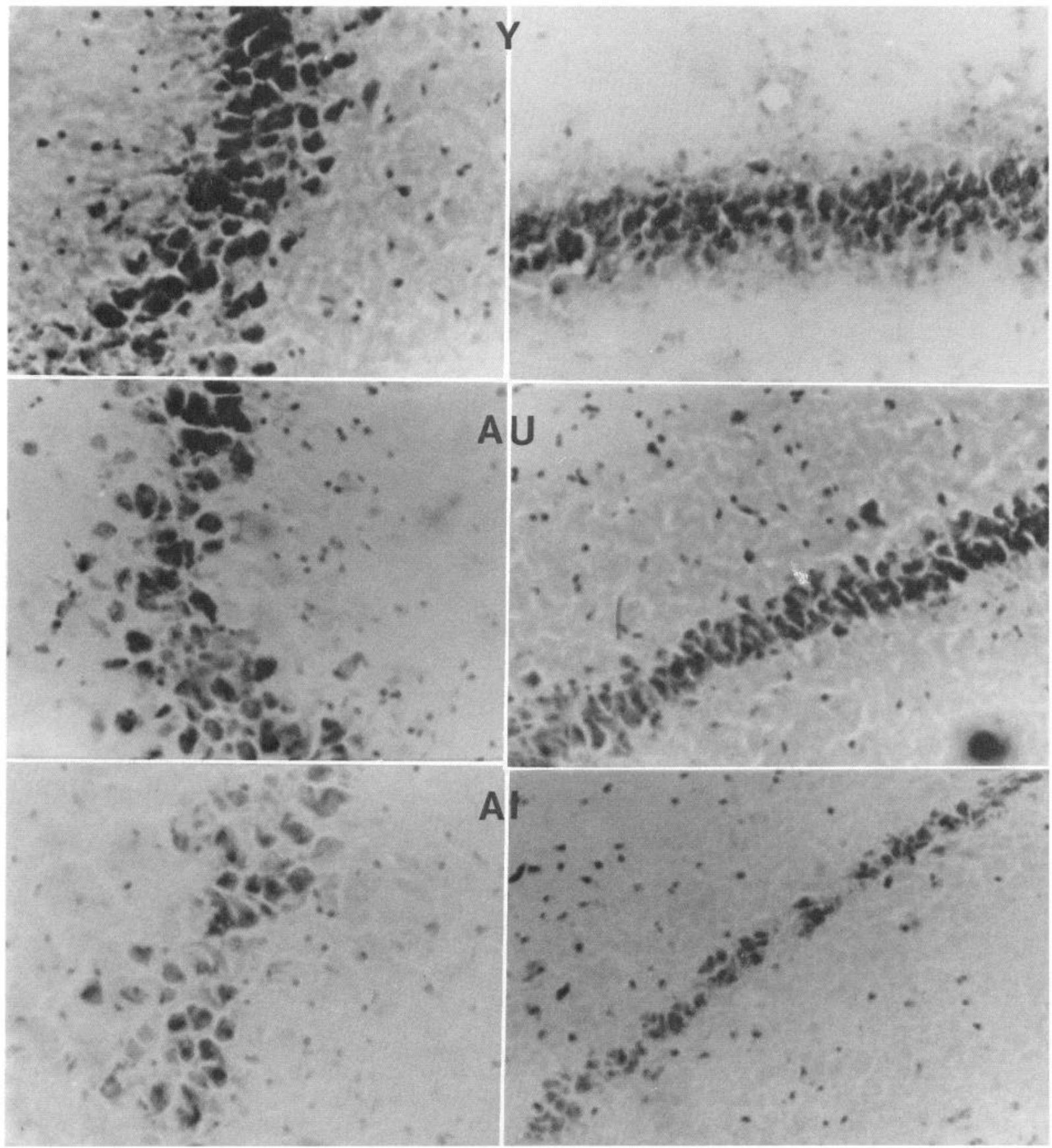

Figure 3. Representative photomicrographs ( $\times 500$ magnification) of Cresyl violet-stained sections showing the $\mathrm{CA}_{3}$ (left panels $)$ and $\mathrm{CA}_{1}($ right panels) cell fields in young control $(Y), A U$, and $A I$ animals.

showed decreased hippocampal NMDA-receptor density compared with both aged, unimpaired animals and young controls. Therefore, spatial memory impairments occur among a select subpopulation of aged rats and appear to be associated with hippocampal pathology. This conclusion is consistent with the finding that hippocampal lesions in young adult rats result in spatial memory deficits (e.g., O'Keefe, 1979; Morris et al., 1982).

The critical question in these studies was whether impaired cognitive performance was selectively related to HPA dysfunction among aged rats. We found that increased HPA activity occurred in the AI, but not the AU animals, and that this difference was apparent under both basal and stressful conditions.
Thus, plasma levels of both ACTH and corticosterone under resting conditions were significantly higher in the AI animals than in either AU or control animals, especially during the dark phase of the cycle. Moreover, while all groups showed comparable increases in plasma corticosterone levels during restraint stress, corticosterone levels remained elevated for a longer period following stress in the AI animals. These findings suggest an impairment in HPA negative-feedback inhibition in the AI animals.

In the present study, both AU and AI animals showed a decrease in type I and type II corticosteroid-receptor binding capacity that was selective to the hippocampus; receptor pop- 


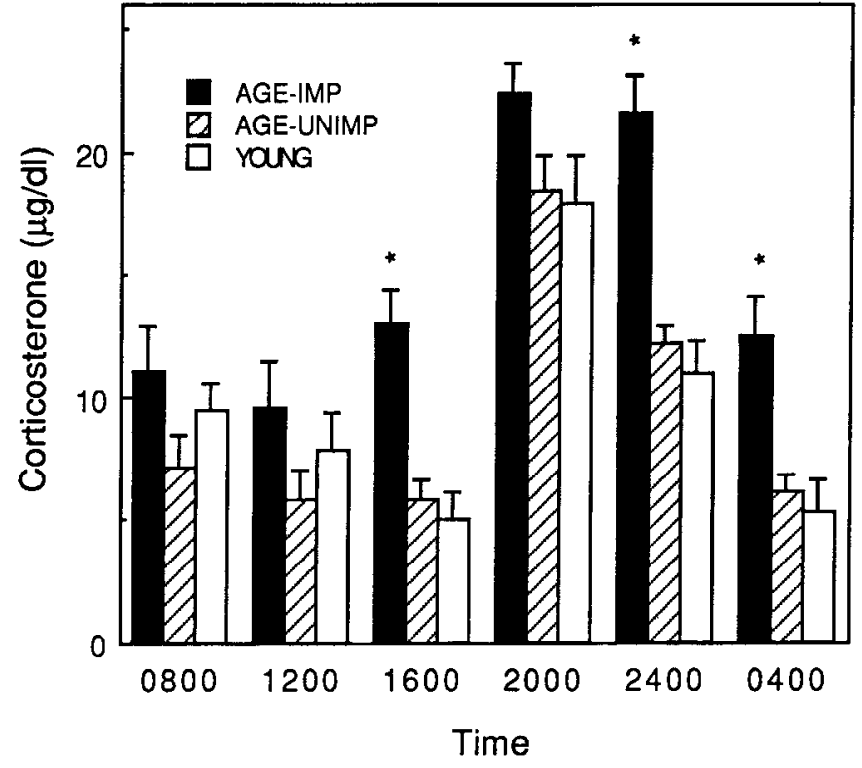

Figure 4. Mean ( \pm SEM) plasma corticosterone levels $(\mu \mathrm{g} / \mathrm{dl})$ in $A I$, $A U$, and young control animals ( $n=10-12$ animals per group) at various times over a 24 -hr cycle $\left(^{*}, p<0.05\right.$ compared with young controls).

ulations in the hypothalamus and pituitary were unaffected. These data are consistent with several previous studies showing a decrease in corticosteroid receptors in the hippocampus of the aged rat (Sapolsky et al., 1983b; Ritger et al., 1984; Meaney et al., 1988a, 1990a,b; Reul et al., 1988). However, the loss of corticosteroid receptors was significantly greater in the AI group, and this increased hippocampal-receptor loss is probably related to the elevated HPA activity in these animals.

There is now considerable evidence for the importance of the hippocampus in the regulation of HPA activity (for reviews, see McEwen et al., 1986; Sapolsky et al., 1986b; Dallman et al., 1987; De Kloet and Reul, 1987). Hippocampal lesions result in elevated corticosterone levels under basal and poststress conditions (e.g., Feldman and Conforti, 1980; Fischette et al., 1980;

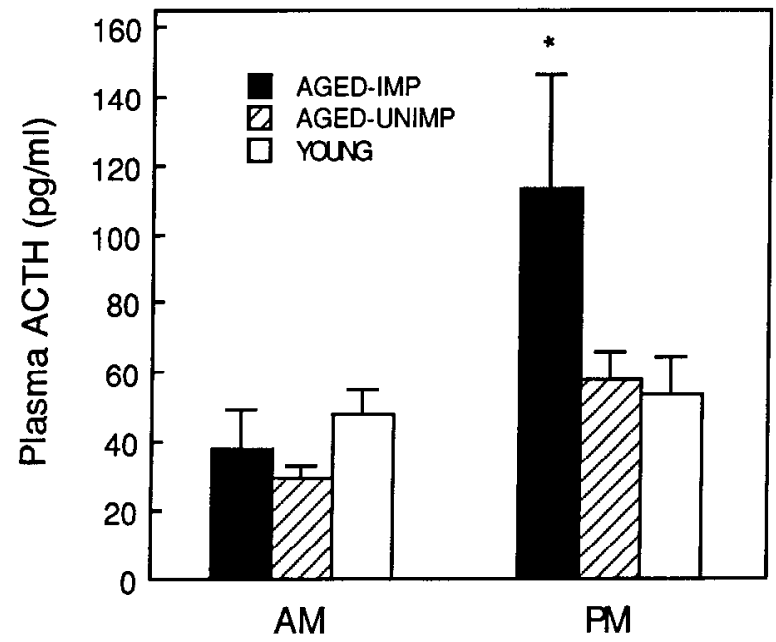

Figure 5. Mean ( \pm SEM) plasma ACTH levels $(\mathrm{pg} / \mathrm{ml})$ in $A I, A U$, and young control animals ( $n=10-12$ animals per group) $2 \mathrm{hr}$ into the light phase $(A M)$ or the dark phase $\left(P M ;^{*}, p<0.05\right.$ compared with young controls).

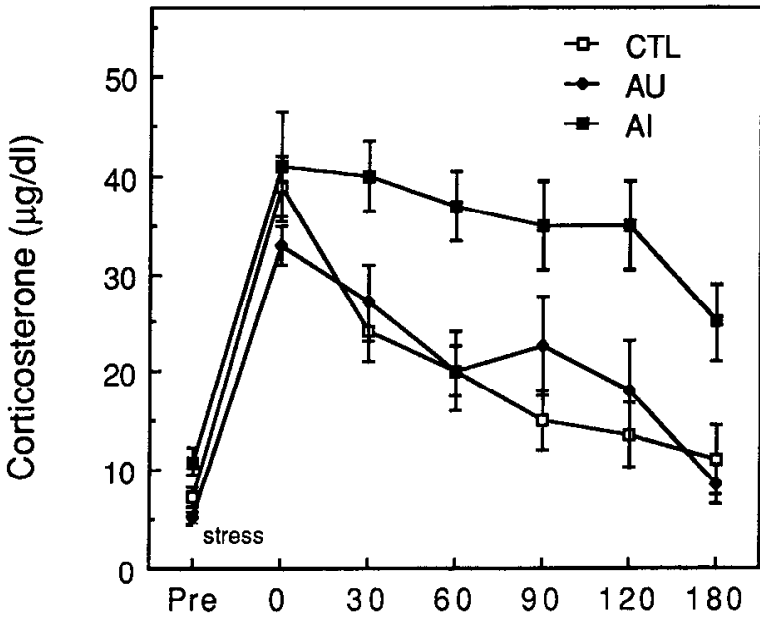

Figure 6. Mean ( \pm SEM) plasma corticosterone levels $(\mu \mathrm{g} / \mathrm{dl})$ in $A I$, $A U$, and young control (CTL) animals ( $n=10-12$ animals per group) at various times before ( $P R E)$, during $(0 \mathrm{~min})$, and following (30-180 min) a 20-min period of restraint stress (AI differ from AU and CTL animals at $30,60,90,120$, and $180 \mathrm{~min} ; p<0.05$ ).

Wilson et al., 1980; Sapolsky et al., 1984a,b) and a reduced suppression of HPA activity following exogenous glucocorticoid administration (Feldman and Conforti, 1976). Hippocampectomy also results in increased CRF and vasopressin mRNA content in the parvocellular region of the paraventricular nucleus (Herman et al., 1989) and increased portal concentrations of ACTH secretagogues (Sapolsky et al., 1989). Moreover, glucocorticoid implants into the hippocampus normalize ACTH levels in adrenalectomized rats (Bradbury and Dallman, 1989). In addition to these anatomical studies, there are also a number of studies showing that decreased hippocampal corticosteroidreceptor density (without cell damage) is consistently associated with glucocorticoid hypersecretion. The Brattleboro ral (Sapolsky et al., 1984a), chronically stressed rats (Sapolsky et al., 1984b), and lactating rats (Meaney et al., 1989b) all show decreased hippocampal corticosteroid-receptor binding, and all hypersecrete corticosterone (Sapolsky et al., 1984a; Stern and Levine, 1974). In the vasopressin-deficit Brattleboro rat, vasopressin therapy reverses the deficit in hippocampal corticosteroid-receptor binding, and as long as the therapy is maintained, corticosterone hypersecretion is alleviated (Sapolsky et al., 1984a).

Hippocampal inhibition of HPA activity appears to involve both type I and type II receptors. Thus, both RU 28318 , an
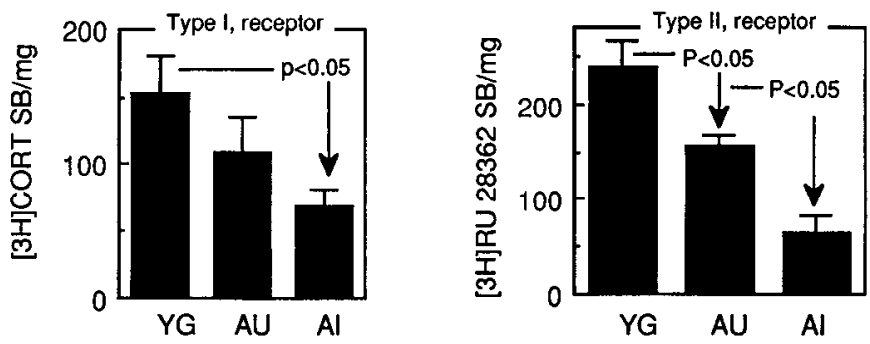

Figure 7. Mean ( \pm SEM) specific binding ( $\mathrm{fmol} / \mathrm{mg}$ protein) for ${ }^{3} \mathrm{H}-$ corticosterone (+ cold RU 28362, type I corticosteroid-receptor binding) and ${ }^{3} \mathrm{H}-\mathrm{RU} 28362$ (type II corticosteroid-receptor binding) in $A I, A U$, and young control $(Y G)$ animals $\left(n=5-6\right.$ animals per group; ${ }^{*}, p<$ $0.05)$. 
antagonist selective for type I sites, and RU 38486, an antagonist selective for type II sites, increase basal and poststress HPA activity (i.e., antagonize endogenous glucocorticoid negative feedback; Ratka et al., 1989). Portal concentrations of ACTH secretagogues are negatively correlated with occupancy of both type I and type II receptors in the hippocampus (Sapolsky et al., 1990). Finally, both type I and type II receptor agonists suppress ACTH release when implanted directly into the hippocampus (Bradbury and Dallman, 1989). These data suggest that, with age, the loss of receptors decreases the sensitivity of the hippocampus to circulating glucocorticoids and dampens negative-feedback efficacy, and there ensues an increase in circulating corticosterone levels under both basal and poststress conditions. Sapolsky et al. (1986a) have previously documented the decreased negative-feedback sensitivity to elevated corticosterone levels in the aged rat. In the present study, the loss of corticosteroid receptors was greatest in the AI animals, and this finding is consistent with the increased HPA activity in these animals.

The present findings parallel our previous work with aged handled and nonhandled animals. Postnatal handling selectively increases type II corticosteroid-receptor density in the hippocampus (Meaney and Aitken, 1985; Meaney et al., 1985, 1987, 1988a, 1989a, 1990a; Sarrieau et al., 1988). Handled animals also show increased negative-feedback suppression of HPA activity in response to either corticosterone or the synthetic glucocorticoid dexamethasone (Meaney et al., 1989a). With age, there is a decrease in hippocampal corticosteroid-receptor density in both handled and nonhandled rats; however, the handled animals continue to show significantly higher type II receptor density than do the nonhandled animals (Meaney et al., 1990a). This situation is analogous to the receptor difference between $\mathrm{AU}$ and $\mathrm{AI}$ animals. As nonhandled animals age, they show increased basal levels of both ACTH and corticosterone (Meaney et al., 1988a, 1990b). As in the present study, this effect is largely specific to the dark phase of the cycle. Aged, nonhandled animals also show increased poststress secretion of corticosterone similar to that seen in the AI animals (Meaney et al., 1988a). These findings indicate that the cumulative exposure to circulating glucocorticoids in the aged, nonhandled animal, like the $\mathrm{Al}$ animal, is markedly elevated. Aged, nonhandled animals also show significant decreases in hippocampal neuron density and spatial memory impairments. In contrast, the aged, handled animals show only a modest increase in poststress secretion of corticosterone and no increase in basal levels of either ACTH or corticosterone. These animals show virtually no decrease in hippocampal neuron density and no evidence of spatial memory impairments, a scenario that is similar to the $A U$ animals in the present study. Taken together, these findings strongly support the idea that increased HPA activity accounts, in part, for individual differences in the occurrence of age-related hippocampal pathology and cognitive deficits. Thus, HPA dysfunction among aged animals is selectively associated with spatial memory impairments and increased hippocampal ncuron loss and does not emerge merely as a function of age.

\section{References}

Abercrombie M (1946) Estimation of nuclear populations from microtome sections. Anat Rec 94:239-247.

Bradbury M, Dallman MF (1989) The effects of hippocampal glucocorticoid type I and type II receptor antagonists on ACTH levels in the PM. Soc Neurosci Abstr 15:716.
Bradford M (1976) A rapid and sensitive method for quantitation of microgram quantities of protein utilizing the principle of protein-dye binding. Anal Biochem 72:248-254.

Brett LP, Chong GS, Coyle S, Levine S (1983) The pituitary-adrenal response to novel stimulation and ether stress in young adult and aged rats. Neurobiol Aging 4:133-138.

Brett LP, Levine R, and Levine S (1986) Bidirectional responsiveness of the pituitary-adrenal system on old and young male and female rats. Neurobiol Aging 7:153-159.

Coirini H, Magarinos AM, DeNicola AF, Rainbow TC, and McEwen BS (1985) Further studies of brain aldosterone binding sites employing new mineralocorticoid and glucocorticoid receptor markers in vitro. Brain Res 361:212-217.

Dallman MF, Akana S, Cascio CS, Darlington DN, Jacobson L, Levin N (1987) Regulation of ACTH secretion: variations on a theme of B. Rec Prog Horm Res 43:113-173.

De Kloet ER, Reul JMHM (1987) Feedback action and tonic influence of corticosteroids on brain function: a concept arising from heterogeneity of brain receptor systems. Psychoneuroendocrinology 12:83105.

DcKosky ST, Schcff SW, Cotman CW (1984) Elevated corticostcrone levels: a possible cause of reduced axon sprouting in aged animals. Neuroendocrinology 38:33-38.

Dilman V (1981) The law of deviation of homeostasis and diseases of aging. Boston: John Wright.

Feldman S, Conforti N (1976) Feedback effects of dexamethasone on adrenocortical responses in rats with fornix lesions. Horm Res 7:5660.

Feldman S, Conforti N (1980) Participation of the dorsal hippocampus in glucocorticoid negative-feedback effect on adrenocortical activity. Neuroendocrinology 30:52-55.

Fischette C, Komisurak B, Ediner H, Feder HH, Siegal A (1980) Differential fornix ablations and the circadian rhythmicity of adrenal corticosterone secretion. Brain Res 195:373-380.

Gage FH, Bjorklund A (1986) Cholinergic septal grafts into hippocampal formation improve spatial learning and memory in aged rats by an atropine-sensitive mechanism. J Neurosci 6:2837-2847.

Gage FH, Kelly PAT, Bjorklund A (1984) Regional changes in brain glucose metabolism reflect cognitive impairments in aged rats. J Neurosci 4:2856-2865.

Herman JP, Patel PD, Schafer MK, Burke S, Akil H, Watson SJ (1989) Evidence for hippocampal regulation of neuroendocrine neurons of the hypothalamo-pituitary-adrenal axis. J Neurosci 9:3072-3083.

Kalimi M, Hubbard JR (1983) Development of an exchange assay for cytosolic glucocorticoid receptors using the synergistic effects of molybdate plus dithiothreitol. Endocrinology 113:1161-1163.

Krey LC, Lu K, Butler W, Hotchkiss J, Piva F, Knobil E (1975) Surgical disconnections of the medial basal hypothalamus and pituitary function in the rhesus monkey. II. GH and cortisol secretion. Endocrinology 96:1088-1096.

Landfield P, Waymire J, Lynch G (1978) Hippocampal aging and adrenocorticoids: a quantitative correlation. Science 202:1098-1101.

Landfield P, Baskin RK, Pitler TA (1981) Brain-aging correlates: retardation by hormonal-pharmacological treatments. Science 214:581583.

Martin CE, Cake MH, Hartmann PE, Cook IF (1977) Relationship between foetal corticosteroids, maternal progesterone, and parturition in the rat. Acta Endocrinol 84:167-176.

McEwen BS, De Kloet ER, Rostene WH (1986) Adrenal steroid receptors and actions in the nervous system. Physiol Rev 66:11211150.

Meaney MJ, Aitken DH (1985) The effects of early postnatal handling on the development of hippocampal glucocorticoid receptors: temporal parameters. Dev Brain Res 22:301-304.

Meaney MJ, Aitken DH, Bodnoff SR, Iny LJ, Tatarewicz JE, Sapolsky RM (1985) Early, postnatal handling alters glucocorticoid receptor concentrations in selected brain regions. Behav Neurosci 99:760-765.

Meaney MJ, Aitken DH, Sapolsky RM (1987) Thyroid hormones influence the development of hippocampal glucocorticoid receptors in the rat: a mechanism for the effects of postnatal handling on the development of the adrenocortical stress response. Neuroendocrinology 45:278-283.

Meaney MJ, Aitken DH, Bhatnagar S, Van Berkel C, Sapolsky RM (1988a) Postnatal handling attenuates neuroendocrine, anatomical, and cognitive impairments related to the aged hippocampus. Science 238:766-768. 
Meaney MJ, Viau V, Bhatnagar S, Aitken DH (1988b) Occupancy and translocation of hippocampal glucocorticoid receptors during and following stress. Brain Res 445:198-203.

Meaney MJ, Aitken DH, Sharma S, Viau V, Sarrieau A (1989a) Postnatal handling increases hippocampal type II, glucocorticoid receptors and enhances adrenocortical negative-feedback efficacy in the rat. Neuroendocrinology 50:597-604.

Meaney MJ, Viau V, Aitken DH, Bhatnagar S (1989b) Glucocorticoid receptors in brain and pituitary of the lactating rat. Physiol Behav 43:209-212.

Meaney MJ, Aitken DH, Sharma S, Viau V (1990a) Basal ACTH, corticosterone, and corticosterone-binding globulin levels over the diurnal cycle, and hippocampal type I and type II corticosteroid receptors in young and old, handled and nonhandled rats. Neuroendocrinology, in press.

Meaney MJ, Aitken DH, Bhatnagar S, Sapolsky RM (1990b) Postnatal handling attenuates certain neuroendocrine, anatomical, and cognitive dysfunctions associated with aging in female rats. Neurobiol Aging, in press.

Mitchell JM, Tatarewicz JE, Meaney MJ (1986) Molybdate stabilizes soluble $\left[{ }^{3} \mathrm{H}\right]$ dexamethasone binding sites in rat brain tissue in incubations at room temperature $\left(22^{\circ} \mathrm{C}\right)$. Brain Res 383:373-376.

Morris RGM (1985) An attempt to dissociate "spatial-mapping" and "working-memory" theories of hippocampal function. In: Neurobiology of the hippocampus (Seifert W, ed), pp 405-432. New York: Academic.

Morris RGM, Garrard P, Rawlins INP, O’Keefe I (1982) Place navigation is impaired in rats with hippocampal lesions. Nature 297:681683.

O'Keefe J (1979) A review of hippocampal place cells. Prog Neurobiol 13:419-439.

Partridge WM, Sakiyama R, Judd HL (1983) Protein-bound corticosterone in human serum is selectively transported into rat brain and liver in vivo. J Clin Endocrinol Metab 57:160-166.

Paxinos G, Watson D (1982) The rat brain in stereotaxic coordinates. New York: Academic.

Pelleymounter MA, Beatty G, Gallager M (1990) Hippocampal ${ }^{3} \mathrm{H}-$ CPP binding and spatial learning deficits in aged rats. Psychobiology, in press.

Philibert D, Moguilewsky M (1983) RU 28362, a useful tool for the characterization of glucocorticoid and mineralocorticoid receptors. Endocrine Soc Abstr ?:335.

Ratka A, Sutanto W, Bloemers M, De Kloet ER (1989) On the role of brain mineralocorticoid (type I) and glucocorticoid (type II) receptors in neuroendocrine regulation. Neuroendocrinology 50:117-123.

Reul JMHM, De Kloet ER (1985) Two receptor systems for corticosterone in rat brain: microdistribution and differential occupation. Endocrinology 117:2505-2511.

Reul JMHM, van den Bosch FR, De Kloet ER (1987) Relative occupation of type-I and type-II corticosteroid receptors in rat brain following stress and dexamethasone treatment: functional implications. J Endocrinology 115:459-467.

Reul JMHM, Tonnaer J, De Kloet ER (1988) Neurotropic ACTH analogue promotes plasticity of type I corticosteroid receptors in brain of senescent male rats. Neurobiol Aging 9:253-257.
Ritger H, Veldhuis H, De Kloet ER (1984) Spatial orientation and hippocampal corticosterone receptor systems of old rats: effects of ACTH4-9 analogue ORG2766. Brain Res 309:393-399.

Rowe JW, Kahn RL (1987) Human aging: usual and successful. Science 237:143-149.

Sapolsky RM, Krey LC, McEwen BS (1983a) The adrenocortical response in the aged rat: impairment of recovery from stress. J Exp Gerontol 18:55-63.

Sapolsky RM, Krey LC, McEwen BS (1983b) Corticosterone receptors decline in a site-specific manner in the aged rat. Brain Res 289:235240.

Sapolsky RM, Krey LC, McEwen BS (1984a) Glucocorticoid-sensitive hippocampal neurons are involved in terminating the adrenocortical stress response. Proc Natl Acad Sci USA 81:6174-6177.

Sapolsky RM, Krey LC, McEwen BS (1984b) Stress down-regulated corticosterone receptors in a site-specific manner. Endocrinology 114: 287-292.

Sapolsky RM, Krey LC, McEwen BS (1985) Prolonged glucocorticoid exposure reduced hippocampal neuron number: implications for aging. J Neurosci 5:1221-1226.

Sapolsky RM, Krey LC, McEwen BS (1986a) The adrenocortical axis in the aged rat: impaired sensitivity to both fast and delayed feedback inhibition. Neurobiol Aging 7:331-336.

Sapolsky RM, Krey LC, McEwen BS (1986b) The neuroendocrinology of stress and aging: the glucocorticoid cascade hypothesis. Endocrinol Rev 7:284-301.

Sapolsky RM, Armanini MP, Sutton SW, Plotsky PM (1989) Elevation of hypophysial portal concentrations of adrenocorticotropin secretagogues after fornix transection. Endocrinology 125:2881-2897.

Sapolsky RM, Armanini MP, Packan D, Sutton SW, Plotsky PM (1990) Glucocorticoid feedback inhibition of ACTH secretagogue release: relationship to corticosteroid receptor occupancy in various limbic sites. Neuroendocrinology 51:328-336.

Sarrieau A, Sharma S, Meaney MJ (1988) Postnatal development and environmental regulation of hippocampal glucocorticoid and mineralocorticoid receptors in the rat. Dev Brain Res 43:158-162.

Sencar-Cupovic I, Milkovic S (1976) The development of sex differences in adrenal morphology and responsiveness to stress of rats from birth to end of life. Mech Ageing Dev 5:1-9.

Slovitar RS, Valiquette G, Abrams GM, Ronk EC, Sollas, AL, Paul LA, Neubort $S$ (1989) Selective loss of hippocampal granule cells in the mature rat brain after adrenalectomy. Science 243:535-538.

Sonntag WE, Golieszek AG, Brodish A, Eldridge JC (1987) Diminished diurnal secretion of adrenocorticotropin (ACTH), but not corticosterone, in old male rats: possible relation to increased adrenal sensitivity to ACTH in vivo. Endocrinology 120:2308-2315.

Stern J, Levine S (1974) Psychobiological aspects of lactation in rats. Prog Brain Res 41:433-444.

Tang F, Philips JG (1978) Some age-related changes in pituitaryadrenal function in the male laboratory rat. J Gerontol 33:377-382.

Wilson M, Greer M, Roberts L (1980) Hippocampal inhibition of pituitary-adrenocortical function in female rats. Brain Res 197:344351 . 